Article

\title{
Climatic Variability and Land Use Change in Kamala Watershed, Sindhuli District, Nepal
}

\author{
Muna Neupane ${ }^{1}$ and Subodh Dhakal ${ }^{2, *}$ \\ 1 Central Department of Environmental Science, Tribhuvan University, Kathmandu 44600, Nepal; \\ nmuna125@gmail.com \\ 2 Department of Geology, Tri-Chandra Campus, Tribhuvan University, Kathmandu 44600, Nepal \\ * Correspondence: dhakalsubodh@gmail.com
}

Academic Editor: Maoyi Huang

Received: 21 December 2016; Accepted: 10 February 2017; Published: 18 February 2017

\begin{abstract}
This study focuses on the land use change and climatic variability assessment around Kamala watershed, Sindhuli district, Nepal. The study area covers two municipalities and eight Village Development Committees (VDCs). In this paper, land use change and the climatic variability are examined. The study was focused on analyzing the changes in land use area within the period of 1995 to 2014 and how the climatic data have evolved in different meteorological stations around the watershed. The topographic maps, Google Earth images and ArcGIS 10.1 for four successive years, 1995, 2005, 2010, and 2014 were used to prepare the land use map. The trend analysis of temperature and precipitation data was conducted using Mann Kendall trend analysis and Sen's slope method using R (3.1.2 version) software. It was found that from 1995 to 2014, the forest area, river terrace, pond, and landslide area decreased while the cropland, settlement, and orchard area increased. The temperature and precipitation trend analysis shows variability in annual, maximum, and seasonal rainfall at different stations. The maximum and minimum temperature increased in all the respective stations, but the changes are statistically insignificant. The Sen's slope for annual rainfall at ten different stations varied between -38.9 to $4.8 \mathrm{~mm}$ per year. Land use change and climatic variability have been analyzed; however, further study is required to establish any relation between climatic variability and land use change.
\end{abstract}

Keywords: Nepal; Kamala watershed; land use; climatic variability, Google earth; ArcGIS

\section{Introduction}

Human activities like population growth, agricultural intensification, and expansion of settlement and industrial areas have created much more land use and land cover changes in the last few decades. Land use refers to the different tasks carried out by humans on the land or the different types of land that provide services and benefits and/or products and resources. Examples of land use include recreation, wildlife reserves, agriculture, roads, and so on, while land cover refers to the biological and physical structures found on the land surfaces [1]. Land cover describes the surface cover on the earth as water bodies, sand, forest, manmade infrastructures, etc. Land cover and land use changes are both often carry-overs from pre-historic periods that are direct and indirect consequences of human activities to obtain essential resources [2]. Thus, the information from both historic and modern time on land use and human activities along with the stability factors may vary rapidly in response to environmental changes or economical needs [3]. Land use change and climate change are interrelated, as these two processes affect each other. Global ecological changes, generated by both land use changes and climate change, are predicted for the future. The interconnectivity between land use change and the atmospheric flux of carbon-dioxide and its consequent impacts on climate are the result of the effects of land use on climate change along with the alteration of climate impact through land management [4]. 
Land use and land cover changes have important consequences on natural resources through their impacts on soil and water quality, biodiversity, and global climatic systems [5]. Land cover change effects are regional and tend to be offset with respect to global temperatures; however, modifications on regional climate are also associated with global warming [6]. Land use is also an important factor influencing the occurrence of rainfall-triggered landslides throughout the world [7]. The land surface characteristics influence surface temperatures and latent heat flux and the contrasting characteristics of adjacent land cover types could induce convection enhancing cloud and precipitation formation [4]. Within two recent decades (the 1980s and 1990s), the temperature anomalies increased all around the globe [8]. Heavy precipitation events have intensified [9] and the reoccurrence of cold nights, cold days, and frost have become lesser while hot days and hot nights are reoccurring more often over the past 50 years [10]. Driving forces of land degradation processes on hill slopes in the tropics are often directly related to changes in land cover or to extreme climatic conditions. Conversion of natural forest to agricultural land to support growing populations have resulted in major changes in soil physical properties such as increase in bulk density, destruction of soil structure, and decrease of organic carbon content [11]. A previous study dealing with the relationship between land use change and climate change clearly showed that land use change had contributed to greater effects on ecological variables in comparison to the effects of climate change [4]. Human activities change land through land management to mitigate climate change and these adaptation actions will have some ecological effects. Likewise, the climate change simulations executed in the U.S. Department of Energy Parallel Climate Model (DOE-PCM) using different scenarios of landscape change during the current century revealed that future land use change decisions could alter IPCC (Intergovernmental Panel on Climate Change) climate change simulations for those based exclusively on atmospheric composition change [6]. The study and analysis of current climatic trends indicates a significant warming trend in recent decades with the effect beings more prominent at higher altitudes. An increase in average mean temperature of $1.2-3{ }^{\circ} \mathrm{C}$ in-between the year 2050 and 2100 is projected. The Himalayan region, particularly Nepal, has also faced increased warming trends, and the significant impacts are prominent [12]. Mann Kendall trend analysis is used for the analysis of rainfall and temperature data. It is a widely used method for trend analysis. The trend analysis helps in identifying the climatic status occurring and climatic changes/variability occurring in a particular area.

In recent years, land use maps have been prepared using satellite images. Remote sensing and Geographic Information System (GIS) are widely used in land use mapping. Different studies around the world incorporate satellite images and image processing in GIS through supervised and unsupervised classifications for land use mapping [13,14]. However, the Landsat images have to be downloaded from Global Land Cover Facility and U. S. Geological Survey, which has a lower spatial resolution of about $30 \mathrm{~m}$. In some cases, a Landsat image of the required year cannot be obtained for some areas. Thus, another way of obtaining satellite images is through the use of Google Earth images, which has a spatial resolution of nearly $1 \mathrm{~m}$. The images are recognizable and the features required can be easily traced. Thus, land use mapping of Kamala watershed was prepared using Google Earth images. However, the images of Google Earth along the south-west region were not clear and were of lower resolution for 2005.

Various developmental activities like migration, deforestation, urbanization, settlement, and infrastructural growth during the last five decades represent the underlying reasons for land cover/ land use change in the Chure (Churiya/ Siwaliks) range of Nepal [14]. The Chure hills are the most recent mountain system of the Himalayan orogeny [15], and the slopes are dry with poor slope development [16]. The fragile geology makes the Chure more susceptible to any form of human disturbances. The maximum temperature data from 49 stations for 1971-1994 showed a warming trend that was increasing by less than $0.03{ }^{\circ} \mathrm{C}$ per year in Siwaliks [17]. The Chure range receives a greater amount and higher intensities of rainfall [14]. As a result, rainfall induced landslides, slope degradation, and floods are major hazards in Chure. The land use change and the climatic changes occurring in the Chure region have had adverse implications on both the environment and 
the livelihood of populations residing in the region. Since 1950s, a huge population has inhabited the Chure range. Settlements and agricultural activities are predominantly located on the flatlands and the river valleys. The slopes are susceptible to debris flow, landslides, bank cutting, and soil erosion, along with flood problems.

The first objective of the study is to identify major land use types along Kamala Watershed and their change pattern between 1995 and 2014. Secondly, the study is conducted to determine the changes in climatic variability within the study area. The detection of land use change provides a brief of the land use practices done and the changes that had been occurred with the pace of industrialization and population centralization to the city areas since past. The land use study covers the changes in different land types; agricultural, settlement, forest and so on. The knowledge on past and present land use practices will ensure the changes that will occur in future and are useful for policy makers and developers. The climatic variability is also the major obstacle for the living in mountainous countries. The information on the changes on climatic parameter will be helpful for the decision makers to get through knowledge, ideas and solutions to cope better with the changing climate and stress. Thus, this research will be helpful in identifying the land use change and climatic variability in Kamala watershed, which is a hazard prone area.

\section{Materials and Methods}

\subsection{Study Area}

Sindhuli district is situated north of Mahabharat range and south of Chure range. The total area of Sindhuli is 2,49,100 ha out of which 1,43,496.5 ha is covered by Chure range. It is located between latitude $26^{\circ} 55^{\prime} \mathrm{N}$ to $27^{\circ} 22^{\prime} \mathrm{N}$ and longitude $85^{\circ} 15^{\prime} \mathrm{E}$ to $86^{\circ} 25^{\prime} \mathrm{E}$. The area ranges between $168 \mathrm{~m}$ and $2797 \mathrm{~m}$ with about $64.83 \%$ of land covered by forest, $19.36 \%$ as agricultural land, $11.55 \%$ landslides and riverbank and $4.41 \%$ used as others. The district incorporates 149 rivers [18]. The study area comprises of Lower Siwaliks, Middle Siwaliks, Upper Siwaliks, Precambrian meta-sedimentary rocks and Lakharpata groups [19]. The Main Boundary Thrust (MBT) is present on southern boundary of the study area. The rocks are soft, loose and easily erodible mainly consisting sandstone, siltstone, mudstone, and conglomerate [20]. Sindhuli is hazard prone zone, which is at risk of multiple natural hazards. The landslides, flood, and debris flows are pervasive due to geological and climatic conditions. Landslides and debris flows are prevalent on hills while there is risk of flood on plain areas of Sindhuli [21]. The extreme precipitation events are one of reason for origination of floods and landslides in this district.

The study area (Figure 1), Kamala watershed lies in Chure range at Sindhuli district of Nepal. The watershed drains to Triveni river (Northwest-Southeast) through Kamala river and other associated rivers. The study area covers eight Village Development Committees namely, Bhadrakali, Ranichuri, Ranibas, Hatpate, Nipane, Sirthauli, Tandi and Harsai and two municipalities: Kamalamai and Dudhauli respectively of Kamala watershed. The study area lies between latitude $27^{\circ} 15.84^{\prime} \mathrm{N}$ to $26^{\circ} 56.69^{\prime} \mathrm{N}$ and longitude $85^{\circ} 53.95^{\prime} \mathrm{E}$ to $86^{\circ} 16.75^{\prime} \mathrm{E}$. Total area covered by the study area is $535.50 \mathrm{~km}^{2}$. The elevation of the study area ranges from 82 to $1700 \mathrm{~m}$. The total population of the study area is 61,793 [22]. The Sindhuli-Bardiwas highway passes through the study area. The Kamalamai municipality is the biggest municipality of the country and headquarters of Sindhuli. The district is populated on city areas since few decades. Figure 2 shows elevation map of study area. 


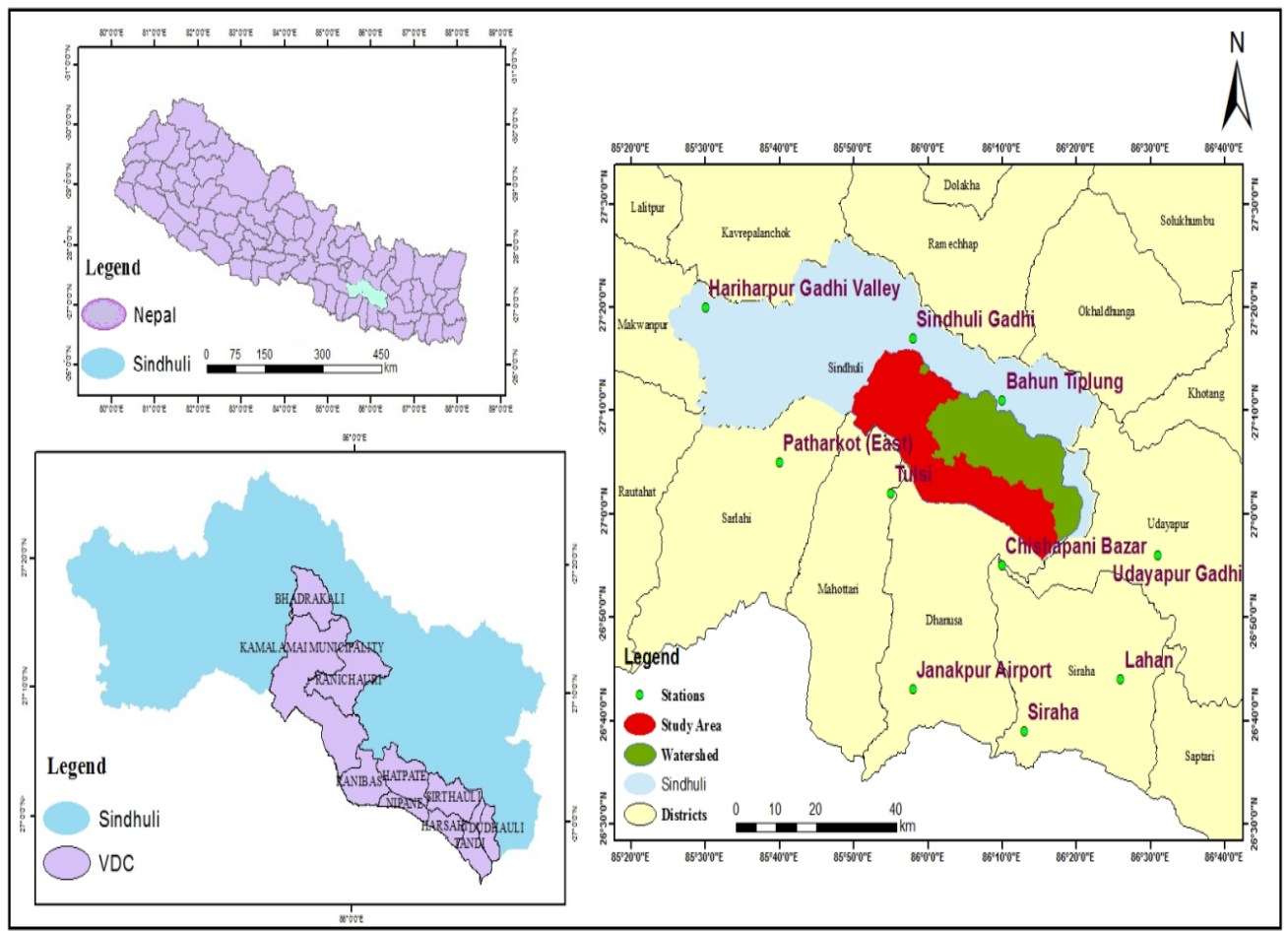

Figure 1. Map of study area.

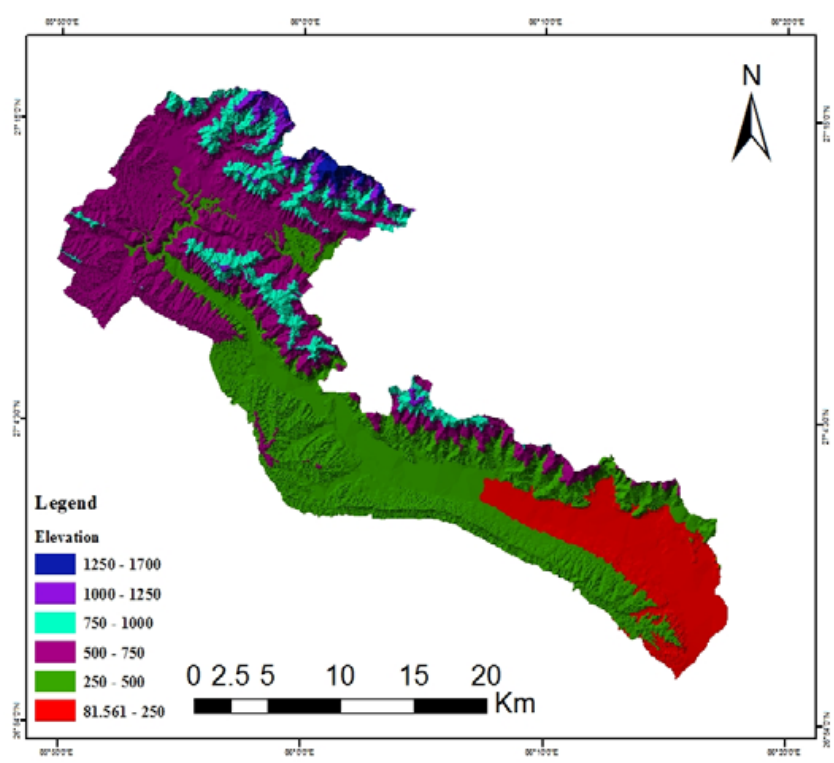

Figure 2. Elevation map of study area.

\subsection{Methodology}

\subsubsection{Land Use Mapping Using Satellite Images and ArcGIS 10.1}

The selection of Area of Interest (AOI) was done using clip tool from map of Nepal. Eleven topo-sheets of 1995 of scale 1:25,000 were collected from Department of Survey, Nepal. The maps were scanned and georeferenced using ArcGIS 10.1 software in Universal Transverse Mercator: WGS 1984 $45 \mathrm{~N}$ projection. The Google Earth was downloaded. The Land Use Land Cover (LULC) mapping was carried out in Google Earth images for the year 2005, 2010 and 2014. The AOI was converted to Google Earth compatible format (.KML) from ArcGIS shape file format. Different land use types 
naming, landslides, forest, cropland, settlement, pond, orchard, river and river terrace were digitized from Google Earth using polygon tool present in it. The digitized LULC types were individually converted to KML file and imported to ArcGIS 10.1 software. The files were then exported to shape file format (.shp). All LULC types were merged using merge tool available in geoprocessing toolbox. The LULC types for all four successive years were also digitized in the similar way. The area for each LULC were calculated. The verification was done through field visit. The Global Positioning System (GPS) locations of the different areas were collected in the field and were overlaid with land use map prepared using Google earth image in ArcGIS 10.1 software as process of validation. The GPS points (150 points in total) of different land use types were collected from each VDC and municipalities within the study area. Table 1 shows land use classification types and their description.

Table 1. Land use classification.

\begin{tabular}{ccc}
\hline S. No. & LULC Type & Description \\
\hline 1. & Forest & All forest type including shrub land \\
2. & Cropland & Land used for cultivation \\
3. & Settlement & Residential, commercial, industrial and minor roads \\
4. & Orchard & Land used for tree cultivation \\
5. & Pond & Manmade water body or reservoir \\
6. & River & Natural water body \\
7. & River Terrace & River bank including barren land \\
8. & Landslides & All landslide types including bank cutting, soil erosion and slope failure \\
\hline
\end{tabular}

\subsubsection{Analysis of Climatic Data}

The climatic data (temperature and precipitation) from 1985 to 2014 (for 3 decades) were collected from Department of Hydrology and Meteorology, Nepal. The trend analysis was conducted for total annual and seasonal rainfall data while the average, minimum, and maximum temperature trend was analyzed using Mann-Kendall trend test at $95 \%$ confidence interval (i.e., alpha $=0.05$ ). The Sen's slope estimator estimates the Sen's slope.

The precipitation data were available from ten nearest stations to the study area namely, Sindhuli Gadhi, Bahun Tiplung, Hariharpur Gadhi, Patharkot (East), Tulsi, Janakpur Airport, Chisapani Bazar, Siraha, Lahan and Udayapur Gadhi. The temperature data were available from only four stations naming Sindhuli Gadhi, Janakpur Airport, Lahan, and Udayapur Gadhi stations (Figure 1). The Sindhuli Gadhi station is the nearest station to the watershed. The missing rainfall values were filled by averaging method [23]. For example, average of total rainfall of 1985 and 1987 was done to fill the missing value of 1986 . The trend analysis was conducted using $R$ software (3.1.2 version) and the graph were plotted in Microsoft excel software 2007. Table 2 shows station type and their location.

Table 2. List of precipitation and temperature stations along the Kamala Watershed.

\begin{tabular}{|c|c|c|c|c|c|c|c|c|}
\hline \multirow[b]{2}{*}{ Stations } & \multirow{2}{*}{$\begin{array}{l}\text { Station } \\
\text { ID }\end{array}$} & \multirow{2}{*}{$\begin{array}{l}\text { Rainfall } \\
\text { (year) }\end{array}$} & \multirow[b]{2}{*}{ District } & \multirow{2}{*}{$\begin{array}{l}\text { Temperature } \\
\text { (year) }\end{array}$} & \multicolumn{2}{|l|}{ Average } & \multirow[b]{2}{*}{ Altitude(m) } & \multirow[b]{2}{*}{ Station Type } \\
\hline & & & & & $\begin{array}{l}\text { Rainfall } \\
(\mathrm{mm})\end{array}$ & $\begin{array}{l}\text { Temp } \\
\left({ }^{\circ} \mathrm{C}\right)\end{array}$ & & \\
\hline $\begin{array}{l}\text { Sindhuli } \\
\text { Gadhi }\end{array}$ & AS1107 & 1983-2014 & Sindhuli & 1989-2014 & 2380.23 & 22.23 & 1463 & Climatology \\
\hline Bahun Tiplung & AS1108 & 1985-2014 & Sindhuli & - & 1743 & - & 1417 & Precipitation \\
\hline $\begin{array}{l}\text { Patharkot } \\
\text { (East) }\end{array}$ & AS1109 & 1985-2014 & Sarlahi & - & 1713 & - & 275 & Precipitation \\
\hline Tulsi & AS1110 & 1985-2014 & Dhanusha & - & 1703.9 & - & 457 & Precipitation \\
\hline $\begin{array}{l}\text { Janakpur } \\
\text { Airport }\end{array}$ & AS1111 & 1985-2014 & Janakpur & 1985-2014 & 1542.1 & 25.04 & 90 & Climatology \\
\hline $\begin{array}{l}\text { Chisapani } \\
\text { Bazar }\end{array}$ & AS1112 & 1985-2014 & Dhanusha & - & 1535.2 & - & 165 & Precipitation \\
\hline $\begin{array}{l}\text { Hariharpur } \\
\text { Gadhi Valley }\end{array}$ & AS1117 & 1985-2014 & Sindhuli & - & 2433.4 & - & 250 & Precipitation \\
\hline $\begin{array}{l}\text { Udayapur } \\
\text { Gadhi }\end{array}$ & AS1213 & 1984-2014 & Udayapur & 1989-2014 & 1641 & 23.88 & 1175 & Climatology \\
\hline Lahan & AS1215 & 1983-2013 & Lahan & 1984-2014 & 1234 & 24.35 & 138 & Agro-meteorology \\
\hline Siraha & AS1216 & 1985-2014 & Siraha & - & 1421.3 & - & 102 & Precipitation \\
\hline
\end{tabular}


Mann-Kendall Trend Test and Sen's Slope Estimation

Mann-Kendall trend test is a non-parametric statistical trend test that does not require data to be normally distributed. The test is used widely for the analysis of trend in climatologic time series [24] and hydrologic time series [25]. In this test, a null hypothesis is set meaning there is no trend and alternative hypothesis meaning there is a trend in set. The test is based on the calculation of Kendall's tau that is a measure of correlation, which measures the strength of the relationship between two variables, which is itself based on the ranks within the samples. The Kendall's tau's values ranges between -1 and +1 . The positive correlation indicates that the ranks of both variables increase together whilst a negative correlation indicates that as the rank of one variable increases, the other decreases. The computational procedure of Mann-Kendall trend test is explained in detail by different authors $[24,26]$.

Sen's Slope is an index to quantify the trend using a non-parametric procedure and developed by Sen [27] and is computed as,

$$
\mathrm{Qi}=\frac{\mathrm{x}_{\mathrm{j}}-\mathrm{x}_{\mathrm{k}}}{\mathrm{j}-\mathrm{k}} \text { for } \mathrm{i}=1,2,3 \ldots \mathrm{N}
$$

where $x_{j}$ and $x_{k}$ are data values at time $j$ and $k(j>k)$, respectively.

\section{Results}

\subsection{Land Use Mapping}

The land use types include forest area, agricultural land, settlement, orchard, pond, river, river terrace, and landslide. The forest area is the dominant land cover/land use type on the study area from 1995 to 2014. The agricultural land covers second highest area after forest. The forest area decreased from 1995 to 2014. Figure 3 shows the land use classification for the year 1995, 2005, 2010, and 2014 respectively. Similarly, the area of pond, river, river terrace, and landslide decreased. The agricultural land, settlement, orchard area however increased. Table 3 shows the land use area on four different years from 1995 to 2014.

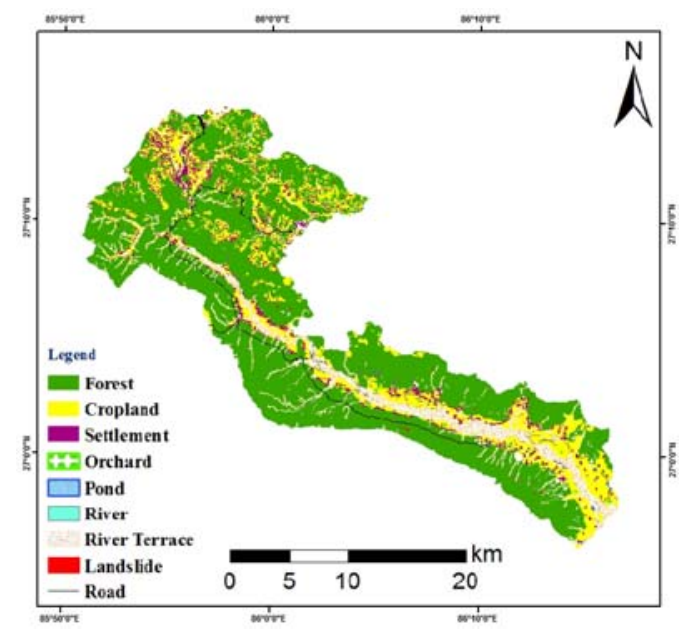

(a)

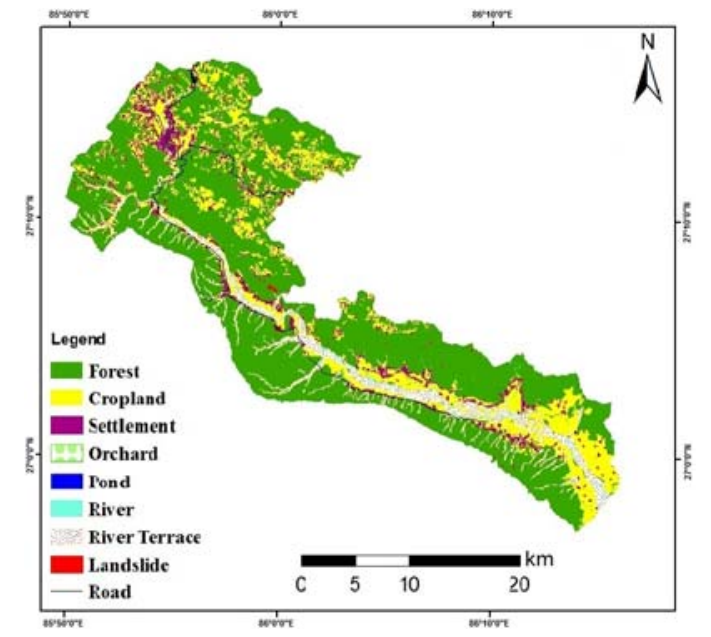

(b)

Figure 3. Cont. 


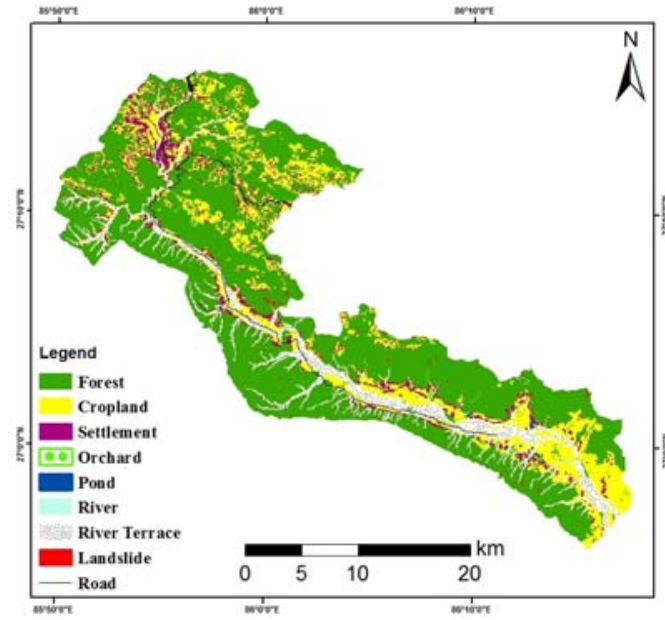

(c)

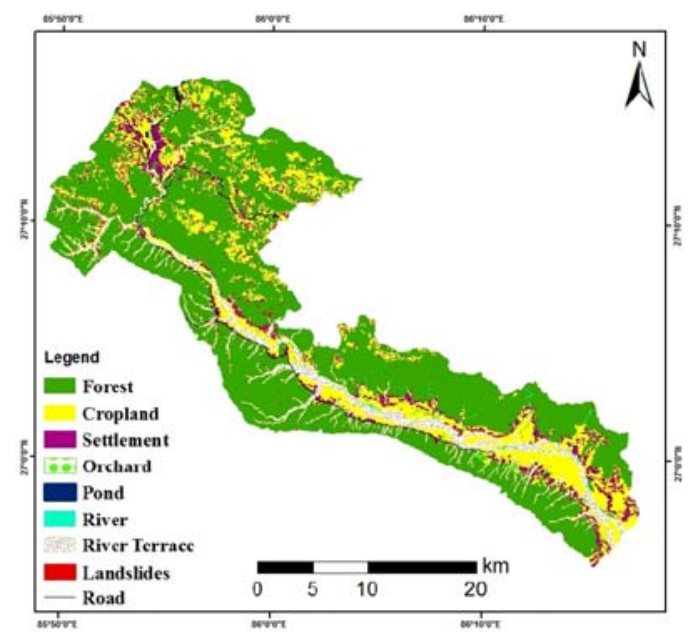

(d)

Figure 3. Land use maps of (a) 1995; (b) 2005; (c) 2010; and (d) 2014.

Table 3. Land use area in hectare and percentage coverage (1995-2014).

\begin{tabular}{lllll}
\hline \multirow{2}{*}{ Land Use } & \multicolumn{3}{c}{$\mathbf{1 9 9 5}$} & $\mathbf{2 0 1 4}$ \\
\cline { 2 - 5 } & Area (ha) & \% Coverage & Area (ha) & \% Coverage \\
\hline Forest & 36,262 & 67.72 & 35,410 & 66.13 \\
Cropland & 11,663 & 21.78 & 12,994 & 24.27 \\
Settlement & 541 & 1.01 & 1398 & 2.61 \\
Orchard & 15 & 0.03 & 99.6 & 0.186 \\
Pond & 3 & 0.01 & 2.4 & 0.004 \\
River & 875 & 1.63 & 554 & 1.03 \\
River Terrace & 4139 & 7.73 & 3042 & 5.68 \\
Landslide & 52 & 0.09 & 50 & 0.09 \\
\hline
\end{tabular}

From 1995 to 2014, the land use types went some changes with decrease in pond area by $20 \%$, river by $36.69 \%$ forest area by $2.35 \%$, landslide area by $3.85 \%$ and river terrace by $26.50 \%$ while agricultural land, orchard area and settlement area increased by $11.41 \%, 546 \%$ and $158.41 \%$ respectively. However, landslide area coverage from 1995 to 2014 decreased by 2 ha. Table 4 exemplifies the land use change occurred between 1995 and 2014.

Table 4. Land use change dynamics (1995-2014).

\begin{tabular}{lllllll}
\hline \multirow{2}{*}{ Land Use } & \multirow{2}{*}{$\mathbf{2 9 9 5}$} & \multirow{2}{*}{$\mathbf{2 0 0 5}$} & $\mathbf{2 0 1 0}$ & $\mathbf{2 0 1 4}$ & \multicolumn{2}{l}{ Change in Land Use from 1995-2014 (\%) } \\
\cline { 7 - 7 } & & & & & Increase & Decrease \\
\hline Forest & 36,262 & 35,785 & 35,583 & 35,410 & - & 2.35 \\
Cropland & 11,663 & 12,581 & 12,823 & 12,994 & 11.41 & - \\
Settlement & 541 & 809 & 929 & 1398 & 158.41 & - \\
Orchard & 15 & 24 & 26 & 99.6 & 564 & - \\
Pond & 3 & 2 & 1 & 2.4 & - & 20 \\
River & 875 & 662 & 590 & 554 & - & 36.69 \\
River Terrace & 4139 & 3617 & 3539 & 3042 & - & 26.50 \\
Landslide & 52 & 70 & 59 & 50 & & 3.85 \\
\hline
\end{tabular}

The majority of land have been converted to agricultural and settlement areas. Mostly, the forest and river terraces are used for agricultural and settlement purposes. The agricultural land on the plain are also used for settlement purposes. However, the orchard area is converted from either cropland or forest. Figure 4 shows conversion of agricultural land to settlement areas at Kamalamai municipality 
from 2005 to 2014 respectively. The GPS points collected from the field on different land use classes were overlaid on the prepared land use map. It was found that $88.66 \%$ of the points were correctly placed onthe land use maps indicating that the accuracy of the land use map is $88.66 \%$.

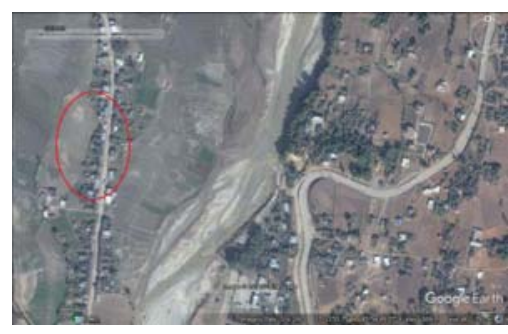

(a)

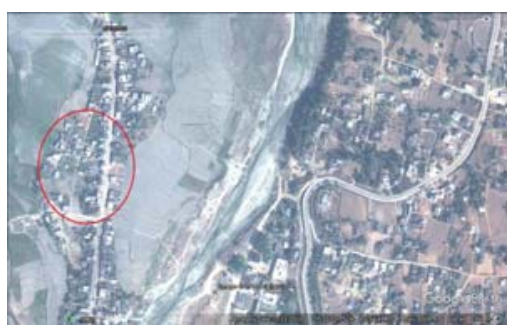

(b)

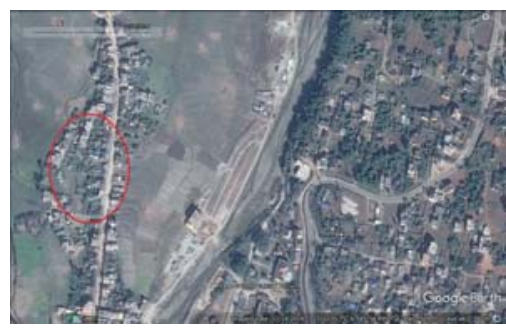

(c)

Figure 4. Land use change observed through google earth along Kamalamai municipality in (a) 2005, (b) 2010 and (c) 2014 .

\subsection{Climatic Data Analysis}

\subsubsection{Rainfall Trend}

The statistical Mann-Kendall trend analysis done using hydro-meteorological data along the study area reveals the variation in annual rainfall. Table 5 demonstrates total annual rainfall trend for 10 stations. The rainfall rate decreased in all stations except Chisapani Bazar and Hariharpur Gadhi Valley. Sindhuli Gadhi, Patharkot (East), Udayapur Gadhi and Lahan obtained significant trend whilst rest other stations have insignificant trend.

Table 5. Total annual rainfall trend for 10 stations.

\begin{tabular}{ccccc}
\hline Stations/Total & $p$-Value & Tau & Sen's Slope & Significance \\
\hline Sindhuli Gadhi & 0.0037 & -0.355 & -38.882 & Significant \\
Bahun Tiplung & 0.29244 & -0.138 & -12.34 & Insignificant \\
Patharkot (East) & 0.00343 & -0.38 & -38.74 & Significant \\
Tulsi & 0.0586 & -0.246 & -15.09 & Insignificant \\
Janakpur Airport & 0.31775 & -0.131 & -7.431 & Insignificant \\
Chisapani Bazar & 0.4978 & 0.0897 & 4.8 & Insignificant \\
Hariharpur Gadhi Valley & 0.56806 & 0.0759 & 6.391 & Insignificant \\
Udayapur Gadhi & 0.0208 & -0.295 & -14.5 & Significant \\
Lahan & 0.00407 & -0.366 & -18.76 & Significant \\
Siraha & 0.56806 & 0.0759 & -6.218 & Insignificant \\
\hline
\end{tabular}

Sindhuli Gadhi, Bahun Tiplung, Patharkot (East), Tulsi, Chisapani Bazar, Lahan noticed negative rainfall trend. Similarly, among these stations, the significant negative trend is observed only on Patharkot (East). Siraha observed positive significant rainfall trend in 30 years. Table 6 shows pre-monsoon rainfall trend for ten stations observed in 3 decades. 
Table 6. Pre-monsoon Rainfall trend.

\begin{tabular}{ccccc}
\hline Stations & $p$-Value & Tau & Sen's Slope & Significance \\
\hline Sindhuli Gadhi & 0.3724 & -0.936 & -2.158 & Insignificant \\
Bahun Tiplung & 0.29244 & -0.138 & -12.34 & Insignificant \\
Patharkot (East) & 0.00343 & -0.38 & -38.74 & Significant \\
Tulsi & 0.4978 & -0.0897 & -1.2 & Insignificant \\
Janakpur Airport & 0.21171 & 0.163 & 1.85 & Insignificant \\
Chisapani Bazar & 0.78896 & -0.0368 & -0.2565 & Insignificant \\
Hariharpur Gadhi Valley & 0.43245 & 0.103 & 2.345 & Insignificant \\
Udayapur Gadhi & 0.83048 & 0.0299 & 0.6278 & Insignificant \\
Lahan & 0.67086 & -0.056 & -0.8417 & Insignificant \\
Siraha & 0.040165 & 0.267 & 3.8 & Significant \\
\hline
\end{tabular}

Bahun Tiplung, Chisapani Bazar and Hariharpur Gadhi Valley shows positive but insignificant rainfall trend. The rainfall trend in Sindhuli Gadhi decreased by $30.422 \mathrm{~mm}$ per year, which is highest among the ten stations and the trend, is significant. The Patharkot (East) and Lahan have significant negative rainfall trend. Table 7 depicts monsoon rainfall trend received on ten stations.

Table 7. Monsoon Rainfall trend.

\begin{tabular}{lllll}
\hline Stations & $\boldsymbol{p}$-Value & Tau & Sen's Slope & Significance \\
\hline Sindhuli Gadhi & 0.00746 & -0.345 & -30.422 & Significant \\
Bahun Tiplung & 0.54826 & -0.081 & 3.319 & Insignificant \\
Patharkot (East) & 0.001907 & -0.402 & -33.81 & Significant \\
Tulsi & 0.060985 & -0.244 & -12.44 & Insignificant \\
Janakpur Airport & 0.17513 & -0.177 & -9.941 & Insignificant \\
Chisapani Bazar & 0.30077 & 0.136 & 8.912 & Insignificant \\
Hariharpur Gadhi Valley & 0.33534 & 0.126 & 4.363 & Insignificant \\
Udayapur Gadhi & 0.054001 & -0.251 & -7.39 & Insignificant \\
Lahan & 0.011887 & -0.32 & -17.03 & Significant \\
Siraha & 0.11226 & -0.207 & -9.275 & Insignificant \\
\hline
\end{tabular}

The post-monsoon rainfall reveals negative trend in all stations. The Sindhuli Gadhi, Tulsi and Udayapur Gadhi received significant trend. Table 8 shows post-monsoon rainfall trend noticed in ten stations.

Table 8. Post-monsoon Rainfall trend.

\begin{tabular}{lllll}
\hline Stations & $p$-Value & Tau & Sen's Slope & Significance \\
\hline Sindhuli Gadhi & 0.0025 & -0.249 & -3.723 & Significant \\
Bahun Tiplung & 0.91 & 0.0173 & -0.987 & Insignificant \\
Patharkot (East) & 0.080391 & -0.228 & -1.87 & Insignificant \\
Tulsi & 0.028178 & -0.285 & -1.525 & Significant \\
Janakpur Airport & 0.45246 & -0.1 & -0.7 & Insignificant \\
Chisapani Bazar & 0.32303 & -0.132 & -1.56 & Insignificant \\
Hariharpur Gadhi Valley & 0.61739 & -0.0667 & -1.115 & Insignificant \\
Udayapur Gadhi & 0.033719 & -0.276 & -3.011 & Significant \\
Lahan & 0.67074 & -0.0561 & -0.2778 & Insignificant \\
Siraha & 0.69459 & -0.053 & -0.3333 & Insignificant \\
\hline
\end{tabular}

The winter rainfall trend for three decade shows negative decreasing rainfall trend in all ten stations. The trend was however significant for Sindhuli Gadhi, Tulsi, Janakpur Airport, Chisapani Bazar and Udayapur Gadhi. Table 9 presents winter rainfall trend and their respective $p-$ value and Sen's slope obtained during 3 decades. 
Table 9. Winter Rainfall trend.

\begin{tabular}{ccccl}
\hline Stations & $p$-Value & Tau & Sen's Slope & Significance \\
\hline Sindhuli Gadhi & 0.00528 & -0.333 & -1.28 & Significant \\
Bahun Tiplung & 0.83639 & -0.03 & -0.482 & Insignificant \\
Patharkot (East) & 0.083379 & -0.226 & -0.8667 & Insignificant \\
Tulsi & 0.028178 & -0.285 & -1.071 & Significant \\
Janakpur Airport & 0.021288 & -0.3 & -1.346 & Significant \\
Chisapani Bazar & 0.01623 & -0.323 & -0.5733 & Significant \\
Hariharpur Gadhi Valley & 0.38193 & -0.115 & -0.5571 & Insignificant \\
Udayapur Gadhi & 0.028111 & -0.286 & -1.073 & Significant \\
Lahan & 0.093608 & -0.218 & -0.7667 & Insignificant \\
Siraha & 0.26079 & -0.148 & -0.6043 & Insignificant \\
\hline
\end{tabular}

\subsubsection{Temperature Trend}

The maximum temperature increased with positive trend in all stations. The minimum and average temperature trend also increased in all four stations. The trends are statistically insignificant for all the stations.

The total annual, pre-monsoon, monsoon, post-monsoon, and winter trend for Sindhuli Gadhi station (1983-2014) and Udayapur Gadhi (1984-2014) along with maximum, minimum and average temperature trend for Sindhuli Gadhi (1989-2014) and Udayapur Gadhi (1989-2014) stations are presented in Figures 5-8 respectively.

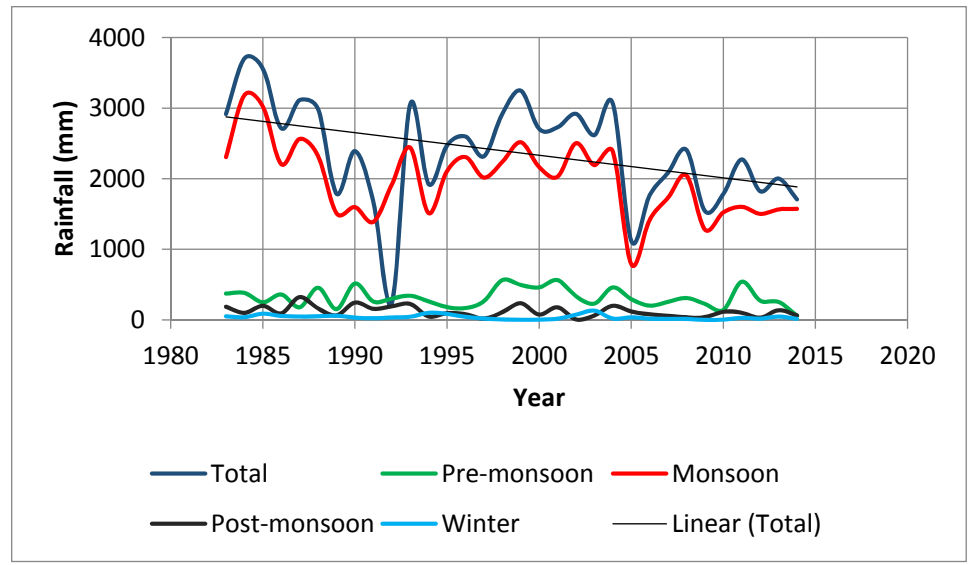

Figure 5. Rainfall trend of Sindhuli Gadhi station.

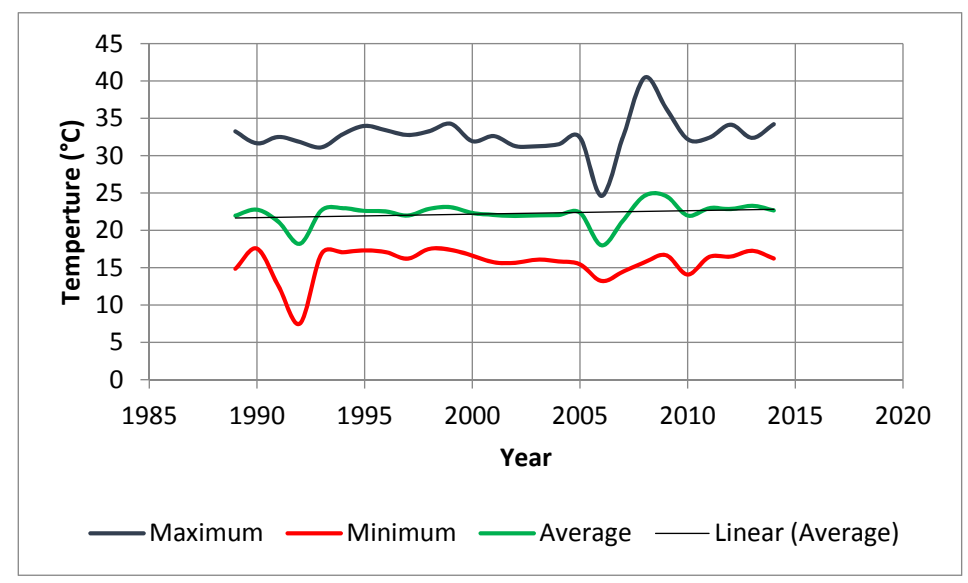

Figure 6. Temperature trend of Sindhuli Gadhi station. 


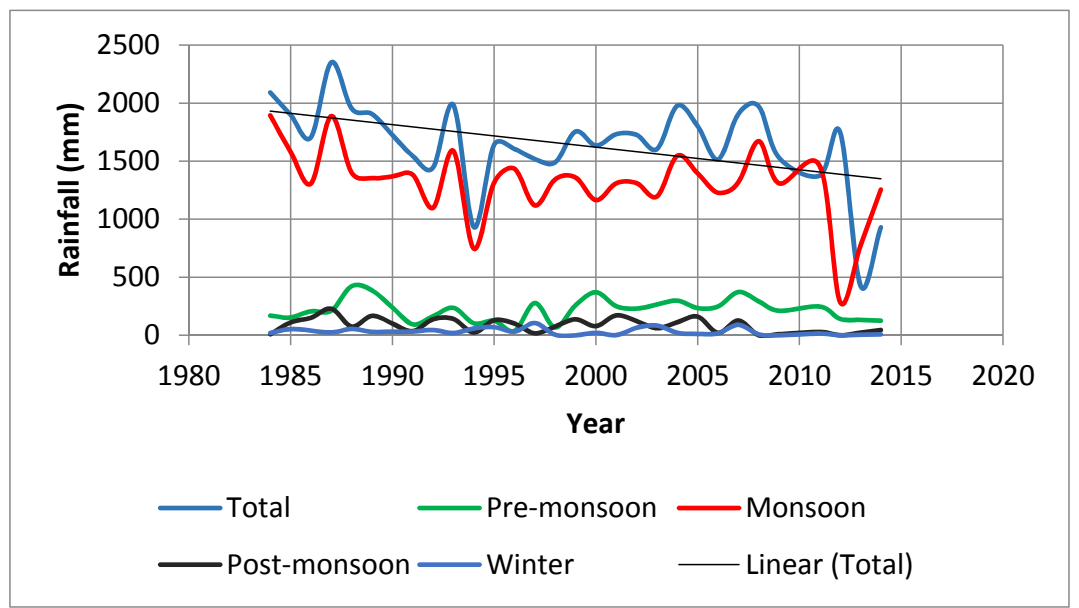

Figure 7. Rainfall trend of Udayapur Gadhi station.

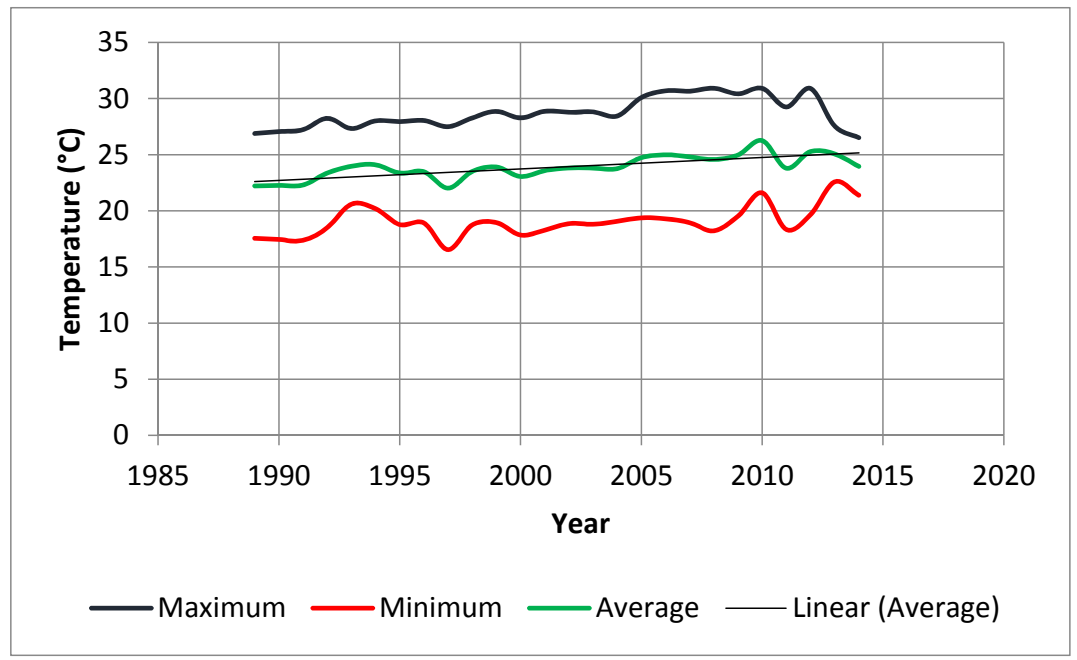

Figure 8. Temperature trend of Udayapur Gadhi station.

\section{Discussion and Conclusions}

The land use map from 1995 to 2014 showed the decrease in forested area and riverbank whereas agricultural land and settlement area increased. The orchard area increased while the pond area decreased. The increase in settlement and agricultural land might be due to population growth in the study area. The clearance of forest for the purpose of cultivation and settlement are the major reason for changes occurred in forest. The land use change in Chure hills started in 1950s after malaria eradication in Terai with government policy for deforestation to raise land revenue [14] along with launching of resettlement program for poor and natural disaster affected people [28]. The agricultural land had increased by $11.41 \%$ from 1995 to 2014 and the river terrace had decreased by $26.50 \%$ by modifying to agricultural land in the study area. The pond area also decreased by $20 \%$ during the same period in the study area. The decrease in pond area might be due to increase in temperature and decrease in rainfall. The temperature trends along the study area on different stations are increasing and shrinkage of pond area is observed. The land cover and land use changes in Chure and the area under cultivation increased by $0.46 \%$ while the forest decreased by $0.40 \%$ between 1990 and 2010. In the same study, in Sindhuli between 1995 and 2010, agricultural land was 19.3\% and 19.7\%, forest was $7.1 \%$ and $4.9 \%$ while for riverbed it was $64.35 \%$ and $66.9 \%$ respectively [14]. The land use change in Nepal is due to two causes; one is natural which includes geological structure relief feature, drainage, climate and another is cultural factor that includes population growth, migration of people 
and infrastructural development [29]. The comparison of landslide area from 1995 to 2005 showed the decrease in landslide area by $3.85 \%$.

The study also includes analysis of temperature and rainfall trend from ten different stations. The temperature trend analysis incorporate average maximum and minimum temperature from four stations whereas the rainfall trend analysis comprises of total, pre-monsoon, monsoon, post-monsoon and winter rainfall trend. The Sen's slope shows the annual rainfall, and seasonal rainfall decreased in Sindhuli Gadhi station. The pre-monsoon rainfall increased along Janakpur Airport, Hariharpur Gadhi, Udayapur Gadhi and Siraha while decreased on other stations. The total annual rainfall increased in Hariharpur Gadhi valley and Chisapani Bazar stations and. The result is in accordance with the result of MoPE (2004) in which the average annual precipitation trend is decreasing in central Nepal [17] and more specifically, all over Nepal is decreasing at the rate of $9.8 \mathrm{~mm} /$ decade [30]. The result is similar to a research conducted in Makwanpur district, which also lies in the Chure with the increase in number of warm days and decrease in cooler days [31]. The variations in rainfall trend obtained in the study area declined in pre-monsoon rainfall at Sindhuli Gadhi, Bahun Tiplung, Patharkot (East), Tulsi, Chisapani Bazar and Lahan out of 10 stations and decrease in winter rainfall in all stations is in accordance with different researches conducted along different places of Nepal [17,31]. The significant station wise annual rainfall trend is obtained in Sindhuli Gadhi, Patharkot (East), Udayapur Gadhi and Lahan. Likewise, the monsoon rainfall trend was found significant for Sindhuli Gadhi, Patharkot (East) and Lahan stations only. This result is similar to annual and monsoon precipitation trend in Nepal in which significant change was attained [17]. The pre-monsoon rainfall trend was significant for Patharkot (East) and Siraha stations only. The temperature trend was positive and statistically insignificant for all four stations. The study of temperature conducted on other parts of the country also shows the insignificant trend [17,32]. This signifies the fluctuation of rainfall events and increase in temperature along the study area and in rest parts of the country. The precipitation and temperature changes are extremely changing and are driving to drier and hotter days. The analysis of rainfall data shows the amounts of rainfall in some years are above the average and for some years below the averages. According to the local inhabitants drying of wells, decreasing of water level in different water sources and drought are some phenomenon occurring in the study area. This erratic rainfall induces the landslides and flood events in the study area. The local people in the study area illustrated the flood occurrence is two to three times a year. A report mentioned the incidence of devastating flood along with high intensity precipitation with consequent landslide and debris flow activities in Kulekhani-Sindhuli area on 19 July to 20 July 1993 [30]. The rainfall initiated number of floods and landslides in the study area each year. The land use pattern, the changes and its uses consequently lead to climate change. The consequence of deforestation causes reduced transpiration that results in less cloud formation, less rainfall and increased drying. Also, the climate change effects are determined by the land use patterns and practices [4]. The decrease in forest area and increased settlement might be a cause for increased temperature in the study area.

The study incorporates mapping of land use change (1995-2014) using topographic maps and Google earth images and climatic variability analysis (3 decades or more) using Mann Kendall trend analysis in Kamala watershed of Sindhuli district. The study area lies in Chure that is hazard prone. The study reveals loss in forest, river terrace and pond area while the settlement, agricultural and orchard area increased during 1995 to 2014 . The settlement increased mostly on the plain areas and the river terraces are converted to agricultural lands. However, the changes in forest area between 1995 and 2014 are not much protrusive. $88.67 \%$ of different features of land use were correctly placed. The climatic variability analysis conducted through Mann-Kendall trend test showed the variability in rainfall and temperature among different stations. The variability in the rainfall pattern among the ten stations over 30 years is estimated. The annual total rainfall increased in Hariharpur Gadhi Valley (6.39 mm/year) and Chisapani Bazar (4.8 mm/year) and decreased on rest of other stations. Similarly, the pre-monsoon rainfall increased on Janakpur Airport, Hariharpur Gadhi Valley, Udayapur Gadhi and Siraha. The monsoon rainfall also increased on Bahun Tiplung, Chisapani Bazar 
and Hariharpur Gadhi Valley only. The post-monsoon and winter rainfall however, decreased on all stations. The temperature trend increased on all four stations. The total annual rainfall trend was significant for Sindhuli Gadhi, Patharkot (East), Udayapur Gadhi and Lahan while for rest of stations, insignificant trend was obtained. The pre-monsoon rainfall trend was significant for Patharkot (East) and Lahan stations only. Likewise, the monsoon rainfall trend was found significant for Sindhuli Gadhi, Patharkot (East) and Lahan stations. The significant post-monsoon rainfall trend was obtained for Sindhuli Gadhi, Tulsi, and Udayapur Gadhi stations. The winter rainfall trend was attained significant for Sindhuli Gadhi, Tulsi, Janakpur Airport, Chisapani Bazar and Udayapur Gadhi stations while it was insignificant for the maximum, minimum and average temperature trends. The land use practices and changes since few decades in the study area might have accelerated the rate of changes of local climate in the study area.

The information on land use change and climatic variability of local level could be beneficial to understand the local effects of land use change and climatic variability/change in a particular area and in policymaking. The climatic data of longer period would have provided the better illustrations of climatic variability and their changes. The detailed study incorporating relationships of land use and climate could provide prolific results on tracing the effects of climate on land use on a particular area and vice versa.

Acknowledgments: The research was financially supported by President Chure-Tarai Madhesh Conservation Development Board and is the outcome of the dissertation conducted at Central Department of Environmental Science, Tribhuvan University. Authors want to thank Kumod Raj Lekhak,. Niraj Bal Tamang and Suman Panday for their support during research. Sanju Ghimire and Muna Khatiwada are acknowledged for their support during fieldwork.

Author Contributions: Muna Neupane and Subodh Dhakal designed the research together. Muna Neupane conducted the literature study, fieldwork and data analysis. Subodh Dhakal supervised the research and guided throughout the study period. Muna Neupane wrote the manuscript and Subodh Dhakal finalized it.

Conflicts of Interest: The authors declare no conflict of interest.

\section{References}

1. Natural Resource Canada. Available online: http://www.nrcan.gc.ca/earth\$-\$sciences/geomatics/ satellite\$-\$imagery\$-\$air\$-\$photos/satellite\$-\$imagery\$-\$products/educational\$-\$resources/9373 (accessed on 13 May 2016).

2. Ellis, E. Land-Use and Land-Cover Change. Available online: http://www.eoearth.org/view/article/ 154143 (accessed on 15 May 2016).

3. Karsli, F.; Atasoy, M.; Yalcin, A.; Reis, S.; Demir, O.; Gokceoglu, C. Effects of land-use changes on landslides in a landslide-prone area (Ardesen, Rize, NE Turkey). Environ. Monit. Assess. 2009. [CrossRef] [PubMed]

4. Dale, V.H. The relationship between land-use change and climate change. Ecol. Appl. 1997, 7, 753-769. [CrossRef]

5. Awasthi, K.D.; Sitaula, B.K.; Singh, B.R.; Bajacharaya, R.M. Land-use change in two Nepalese watersheds: GIS and geomorphometric analysis. Land Degrad. Dev. 2002, 13, 495-513. [CrossRef]

6. Feddema, J.J.; Oleson, K.W.; Bonan, G.B.; Mearns, L.O.; Buja, L.E.; Meehl, G.A.; Washington, W.M. The importance of land-cover change in simulating future climates. Science 2005, 310, 1674-1678. [CrossRef] [PubMed]

7. Glade, T. Landslide occurrence as a response to land use change: a review of evidence from New Zealand. Catena 2003, 51, 297-314. [CrossRef]

8. Caesar, J.; Alexander, L.; Vose, R. Large-scale changes in observed daily maximum and minimum temperatures: Creation and analysis of a new gridded data set. J. Geophys. Res. Atmos. 2006, 111, 1-10. [CrossRef]

9. Gassner, C.; Promper, C.; Beguería, S.; Glade, T. Climate change impact for spatial landslide susceptibility. In Engineering Geology for Society and Territory-Volume 1; Springer International Publishing: Basel, Switzerland, 2015. 
10. Field, C.B.; Barros, V.R.; Mach, K.J.; Mastrandrea, M.D.; van Aalst, M.; Adger, W.N.; Arent, D.J.; Barnett, J.; Betts, R.; Bilir, T.E.; et al. Climate Change 2014: Impacts, Adaptation, and Vulnerability. Part A: Global and Sectoral Aspects; Contribution of working group II to the fifth assessment report of the intergovernmental panel on climate change; Cambridge University Press: Cambridge, UK, 2014.

11. Matson, P.A.; Vitousek, P.M. Cross-system comparisons of soil nitrogen transformations and nitrous oxide flux in tropical forest ecosystems. Glob. Biogeochem. Cycles 1987, 1, 163-170. [CrossRef]

12. Agrawal, S.; Raksakulthai, V.; Van Aalst, M.; Larsen, P.; Smith, J.; Reynolds, J. Development and Climate Change in Nepal: Focus on Water Resources and Hydropower; Organization of Cooperation and Development: Paris, France, 2003.

13. Otieno, V.O.; Anyah, R.O. Effects of land use changes on climate in the Greater Horn of Africa. Clim. Res. 2012, 52, 77-95. [CrossRef]

14. Ghimire, M. Land Use and Land Cover Change in the Churia-Tarai Region, Nepal; Ministry of Forest and Soil Conservation: Kathmandu, Nepal, 2012.

15. Gansser, A. Geology of the Himalayas; John Wiley \& Sons: London, UK, 1964.

16. Ghimire, M. Landslide occurrence and its relation with terrain factors in the Siwalik Hills, Nepal: Case study of susceptibility assessment in three basins. Nat. Hazards 2011, 56, 299-320. [CrossRef]

17. Shrestha, A.B.; Wake, C.P.; Mayewski, P.A.; Dibb, J.E. Maximum temperature trends in the Himalayas and its vicinity: An analysis based on temperature records from Nepal for the period 1971-94. J. Clim. 1999, 12, 2775-2787. [CrossRef]

18. DDMC. Disaster Preparedness Plan 2068 BS, Sindhuli; District Disaster Management Committee: Sindhuli, Nepal, 2011.

19. DMG. Geological Maps of Petroleum Exploration Block-8, Janakpur, Central Nepal; [map]; Petroleum Promotion Exploration Project, Department of Mines and Geology, Government of Nepal: Kathmandu, Nepal, 2004.

20. Dhakal, S. Evolution of geomorphologic Hazards in Hindu Kush Himalaya. In Mountain Hazards and Disaster Risk Reduction; Springer: Tokyo, Japan, 2015; pp. 53-72.

21. Government of Nepal, Ministry of Environment. National Adaptation Programme of Action (NAPA) to Climate Change; Ministry of Environment: Kathmandu, Nepal, 2010.

22. CBS. Statistical Year Book of Nepal; Central Bureau of Statistics: Kathmandu, Nepal, 2011.

23. Singh, R.B.; Mal, S. Trends and variability of monsoon and other rainfall seasons in Western Himalaya, India. Atmos. Sci. Lett. 2014, 15, 218-226. [CrossRef]

24. Mavromatis, T.; Stathis, D. Response of the water balance in Greece to temperature and precipitation trends. Theor. App. Climatol. 2011, 104, 13-24. [CrossRef]

25. Yue, S.; Wang, C. The Mann-Kendall test modified by effective sample size to detect trend in serially correlated hydrological series. Water Resour. Manag. 2004, 18, 201-218. [CrossRef]

26. Karmeshu, N. Trend Detection in Annual Temperature \& Precipitation using the Mann Kendall Test-A Case Study to Assess Climate Change on Select States in the Northeastern United States. Master's Thesis, University of Pennsylvania, Pennsylvania, PA, USA, 2012.

27. Poudel, S.; Shaw, R. The Relationships between Climate Variability and Crop Yield in a Mountainous Environment: A Case Study in Lamjung District, Nepal. Climate 2016, 4, 13. [CrossRef]

28. Joshi, A.L.; Shrestha, K.; Sigdel, H. Deforestation and participatory forest management policy in Nepal. Underlying Causes of Deforestation and Forest Degradation in Asia. World Rainforest Movement. Available online: http:/ /www.wrm.org.uy/deforestation/Asia/Nepal.html (accessed on 5 August 2016).

29. Shrestha, S.H. A review of land use pattern in Nepal. Himal. Rev. 1975, 7, 33-42.

30. WECS. Water Resources of Nepal in the Context of Climate Change; Water and Energy Commission Secretariat: Kathmandu, Nepal, 2011.

31. Paudyal, P.; Kafle, G. Assessment and prioritization of community soil and water conservation measures for adaptation to climatic stresses in Makawanpur district of Nepal. J. Wetl. Ecol. 2012, 6, 44-51.

32. Dhakal, S.; Sedhain, G.K.; Dhakal, S.C. Climate Change Impact and Adaptation Practices in Agriculture: A Case Study of Rautahat District, Nepal. Climate 2016, 4, 63. [CrossRef]

(C) 2017 by the authors; licensee MDPI, Basel, Switzerland. This article is an open access article distributed under the terms and conditions of the Creative Commons Attribution (CC BY) license (http:/ / creativecommons.org/licenses/by/4.0/). 